\title{
A Hybrid Multi-Criteria Model for Insurance Companies Rating
}

\author{
Saeid Khodamoradi ${ }^{1}$, Amir Safari ${ }^{2} \&$ Razieh Rahimi ${ }^{1}$ \\ ${ }^{1}$ Industrial Management Department, Faculty of humanities Sciences, Shahed University, Tehran, Iran \\ ${ }^{2}$ Central Insurance of IR. Iran, Tehran, Iran \\ Correspondence: Saeid khodamoradi, Industrial Management Department, Faculty of humanities Sciences, \\ Shahed University, Tehran, Iran. Tel: 98-21-5121-2400. E-mail: Saeed379@yahoo.com
}

Received: February 2, 2014

doi: 10.5539/ibr.v7n6p150
Accepted: March 20, 2014

Online Publication: May 27, 2014

URL:http://dx.doi.org/10.5539/ibr.v7n6p150

\begin{abstract}
Most of the current rating methods depend on financial information and solvency level or tangible capitals of insurance companies. Considering intangible capitals in evaluating and rating of the companies has been emphasized by many investigators. A key point in this regard is how the intangible criteria are identified and incorporated along with tangible criteria through a rating process. Application of combined multiple criteria decision making methods have special efficiency. For this, important criteria in rating process are first screened by experts' opinions. DEMATEL method is then used here to authenticate the identified criteria and retain a logical collection of them. Finally, multiple criteria decision-making method PROMETHEE II is applied. Using data from a sample of insurance companies listed in Tehran Stock Exchange for a period of 2010-2012 and applying the combined method, it was observed that Alborz Company has the highest and Dana Company has the lowest rate. Application of the Content Analysis for identification of intangible capitals constitutes the novelty of our investigation.
\end{abstract}

Keywords: insurance, rating, intangible capital, multiple criteria decision making

\section{Introduction}

Insurance industry is a major economic institute. On one hand, insurance is a financial institute playing critical role in fortifying economical vigor of the society and, on the other hand, paves the way for extension of production and services activities through establishing a secure and reliable medium. In addition to providing economical security via offering insurance services, insurance companies can play a vital role in dynamism and activity of financial markets by accumulation and application of great deal of financial resource they obtain in interval between receiving premium and payment for compensation; the insurance institutes can support financial resource of many economical activities and investment in production sections (Hassanzade et al., 2010). Judgment on adoption of the best insurance company is an important issue demanding detailed investigation. A common method for evaluation of insurance companies is to rank them (Mirzayi, 2002). Rating the insurance companies and financial/nonfinancial information obtained in rating process is a powerful tool for decision making because it evaluates rating criteria from various aspects (Amin \& Kamalkhani, 2009).

Until recently, only tangible capitals were considered in evaluating and rating of the companies. However a large number of studies conducted on the role of intangible capitals have revealed another fact. Intangible capital is an issue has been extensively investigated during recent years. In the present work, intangible capitals have been used as an important criterion of evaluation in the proposed model. The investigation tries to find out if it is possible to design and applied and practical pattern for rating of insurance companies in Iran based on both tangible and intangible capitals. The main goal of the present study is to propose a model for rating of Iranian insurance companies. Inclusion of intangible capital is the innovative aspect of the work. Sub purposes of the study include:

- Identifying influencing criteria of tangible and intangible capitals for evaluation and rating of insurance companies in Iran;

- Achieving an integrated model of tangible and intangible capitals in the studied population;

- Application of multivariable methods in insurance companies rating. 


\section{Literature Review}

Rating process includes qualitative, quantitative, and legal analyses. Quantitative analyses usually include financial analysis based on financial reports of companies. Qualitative analyses are based on analyzing management quality and include investigating competition of company, its expected growth in related industry and company weaknesses in relation to technological changes, regulations changes and labor/workers relations (Zekawat, 2003). Rating has not been seriously applied in Iran and only a few institutions determine some criteria and introduce the supreme firms based on these criteria. The most notable examples of these institutions are Iranian institution of industrial management and banking and insurance department of ministry of economic affairs and finance (Islami, 2011).

Generally, the main goal of insurance companies rating is to evaluate reliability of the insurance companies (Safari \& Mirzayi, 2009). Simply speaking, rating is a complex assessment of financial status of insurance companies performed by experts, which is considered as a main element of non-price competition in market (Safari \& Mirzayi, 2009). Rating of insurance companies and financial and nonfinancial information achieved by rating is a powerful tool for decision making and market research for insurance agencies, agents, executive managers of risk control, managers of pension funds, investment banks, mangers of insurance companies, insurers and more importantly costumers of insurance companies (Safari \& Mirzayi, 2009). Consequences of rating of insurance companies are:

- Firm development (acceptance by agents and agencies).

- Assisting supervisory institutes in financial supervision.

- Buying reinsurance.

- Assistance in decision making by investors including individuals (natural or legal) who are going to buy stocks of insurance company or banks and credit institutes who want to give loan to the insurance company.

- And the most importantly, decision making by costumers of insurance products.

There are limitations and obstacles against comprehensive evaluation and logical analysis for rating of Iranian insurance companies, three of which are:

1) Access to the latest and most exact statistics and performance information (including financial and operational information) of all companies.

2) Lack of homogeneity in performance of the studied companies.

3) Lack of consistency in accounting methods and policies and financial reporting methods (Yari, 2010).

This study aims tangible and intangible criteria, which are assessed on the basis they'll continue to investigate.

\subsection{Identification and Classification of (Financial) Tangible Criteria}

Analyzing companies' performance based on financial ratios and criteria is the most critical step in the process of rating of companies. In this regard, minimum and maximum criteria and mechanisms for evaluation of companies' performance have been proposed, however standard limit of these scales has not been determined for insurance industry in Iran. Generally, performance of insurance company according to financial ratios is evaluated in this manner:

- Solvency level: is based on ability of the company in dept payment and performing the obligations.

- Profitability and performance rate: achieving profitability shows firm success and stability and managers' efficiency on one hand, and desirable performance of investment for all investors on the other hand.

- Leverage: shows limits of supplying financial needs of the company.

- Activity: help evaluate assets used in the institute (Yari, 2010).

\subsection{Describing the Concepts Related to Intangible Capitals}

Today's economy depends on potential and emerging power of human force approach and increasing pivotal role of intangible assets and intellectual capital. Superior commercial performance makes the company retain its competitive power. This attempt in industry section has taken an inhibitory form mainly due to advent of new competitors, patents and governmental regulations. These obstacles have been eliminated by technological changes, quick innovations and omitting hindering regulations; because survival and superior performance require flexibility, innovation and market entering speed and competitive advantage is originated from internal resources and capabilities of individual organization including ability to develop and retain reliable and 
committed human force (Ahmadi \& Rahmanpour, 2009). Differences between tangible and intangible capitals are described with more details in Table 1.

Table 1. Tangible versus intangible capitals

\begin{tabular}{ll}
\hline Intangible capitals & Tangible capitals \\
\hline Can't be observed & Can be observed \\
Are difficult to quantify & Can be quantified \\
Can't be traced by accounting & Are a part of balance sheet \\
Are evaluated by assumptions & Investment in these capitals has a certain performance \\
Can't be purchased or copied & Can be easily increased \\
Their value is increased by purposeful application & Are depreciated by application \\
Have multiple applications without losing value & Have defined application \\
Are best managed by frequency mentality & Are best managed by scarcity mentality \\
Are best increased by alignment & Are best increased by control \\
Are dynamic and temporary when they are not used & Can be accumulated and stored \\
\hline
\end{tabular}

Reference: Hobertsen-Anje, management conference, buston, 1996, October $17^{\text {th }}$.

According to Leef Edvinson and Michele malone, intellectual capital is composed of three major components:

1) Human capital: people who are source of innovation.

2) Structural capital: tools applied for knowledge transfer and division.

3) Relational capital (costumer): the relationships creating value in business.

Intellectual capital is created by interaction among the human capital, structure and relation (Bentis, 2000). The correlation is presented in the figure below (Khavandkar \& Mottaghi, 2009).

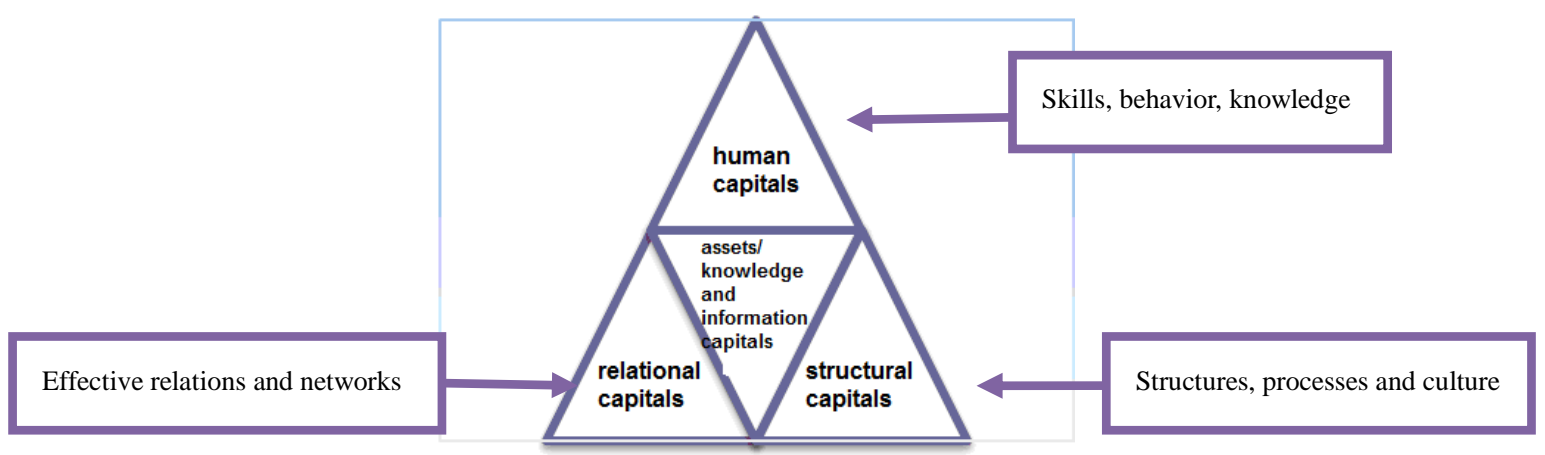

Figure 1. Schematic presentation of interactions among human capitals, structural capitals, relational capitals and assets/information and knowledge capitals and factors influencing them in context of intellectual capital

\subsection{Intangible Capitals Measurement}

Despite increasing growth of intangible assets and intellectual capital, most of accounting systems use traditional methods and cannot reveal the intellectual capitals. However, importance of disclosure of non-balance sheet items and intangible assets in annual report, especially in reports of firms that are well known in public, is increasing (Anvari, Rostami, \& Seraji, 2005). Since Iranian companies present their performance report in ordinary annual public meetings as board activity report to stakeholders, these reports can be an appropriate source for evaluation of intellectual capital criteria in Iranian firms. The best resource to achieve these reports is website of Tehran stock exchange (Ghareshi, 2010). 
Here some examples of investigations performed in rating of insurance companies are presented:

An investigation entitled "comparative evaluation of financial performance of Iranian and foreign insurance companies and their rating" was conducted by Safavi and Falahati in 2007 and published in Journal of Business Investigations. In this investigation, the most important criteria for financial performance of insurance companies were described and estimated for domestic and foreign companies using data of 2004. Numerical taxonomy method was used for indentifying the rank of each insurance company.

Hasanzadeh and Zare (2008) conducted an investigation entitled "identifying financial performance criteria of private insurance companies using balanced scorecard approach with experts' opinion" published in seasonal of insurance industry. The goal of this investigation was to identify performance criteria and criteria of private insurance companies to propose a performance evaluation pattern. Based on documentary study and interviewing with experts and managers of insurance companies, the main performance criteria in four fields as financial, market, costumer and internal processes and growth and development were indentified. Using questionnaire and expert comments and by means of imaginography, degree of importance of each criterion was determined and a primary model was proposed for performance assessment of private insurance companies.

An investigation entitled "assessing rating of companies based on accounting and non-accounting information and comparing this rating to that of Tehran stock exchange" was carried out by Meharni et al. (2009) and published in journal of development and capital. The goal of the study was to clarify if the companies with top rank in Tehran stock exchange are superior to other firms based on financial and nonfinancial criteria of performance evaluation. Non-accounting variables: economical value added, Jensen ration, sharp ratio, Torino ratio. Accounting variables: return on asset, liquidity, capital structure, cash conversion cycle, firm size. Results of correlation analysis showed that there was weak correlation between companies rating based on stock exchange criteria and their ranking based on the investigated variables suggesting that the companies with top rate in Tehran stock exchange are not necessarily superior to other companies.

A study entitled "application of balanced and VIKOR scorecard in rating of insurance companies" was conducted by Amiri et al. (2009) which was published in Journal of insurance. The companies were rated based on VIKOR method and balanced scorecard in this investigation. The criteria were determined by literature review and experts' opinions and after factor analysis, weights of the variables were assigned based on factors special rate as inputs of VIKOR and finally the insurance companies were rated.

In an investigation carried out by Braket and Cooper (2004), ability to afford the commitments against performance and difference in organizational forms and marketing in US properties and responsibility insurance companies was investigated. In this study, efficiency of insurance companies was estimated using envelopment analysis.

Bern et al. (2006) published an article entitled "multi-criteria credit rating: credit rating process for Italian companies according Basel committee 2". Multiple criteria decision making method (fuzzy method) was used for credit rating and classification of criteria was performed based on guidelines of Basel committee 2. The model was used in selected Italian companies.

An investigation entitled "analysis and anticipation of rating of insurance companies" was conducted by Vangester et al. (2007). In this study, the relationship between financial ratios and rating for various types of insurance companies was analyzed which are achieved by advanced statistical methods. Results of rating model approach are similar to those of reduced portfolio approach which used a series of descriptive variables.

Vanlier and Bizens conducted an investigation entitled "development of a simple and intuitive rating system under solvency system2" in Belgium (2010). This paper proposed a method compatible with guidelines of Basel committee 2, which forecasts credit rating of insurance companies and compare their performance to foreign rating. Criteria used in this model were taken from criteria of Endpors standard company. The variables included: profitability, solvency, liquidity, value added and size. Estimation was performed by ordinal logistic regression.

Damlz and Zoponidis conducted an investigation entitled "multiple criteria decision making system for bank rating" in Greece (2010). It was a case study investigating lay out of a multiple criteria approach for rating of bank. The methodology was based on PROMETHEE II executed in a consistent decision making supporting system. The criteria were selected according to camels rating system.

Literature review shows that in most of the cases, financial criteria were used for evaluating and rating of major companies including banks, insurance companies and firms accepted in stock exchange and rating has been performed based on financial power of the companies. However, organizations power is not limited to tangible resources and capitals. Moreover most of studies investigating intangible capitals have been either conducted 
separately or have applied balanced scorecard method which is a descriptive model of evaluation of intellectual capitals. In the present study, however, intellectual capital has been investigated by a regulating approach using intellectual capital reporting process.

Rating of insurance companies in Iran has not been conducted by an authenticated institute yet. Central insurance institute performed rating of insurance companies during 1386 and 1387. In this study conducted by means of some financial and nonfinancial criteria, no known methodology was used and the results of rating was not reported. It seems that Iran central insurance and insurance scientific institute are attempting to design a method for rating of insurance companies. No result has been reported yet.

\section{Methodology}

Methodology used in this investigation is summarized in Figure 2. The methodology is based on a systematic approach. At the first step, utilizing relevant literature, all possible qualitative and quantitative criteria are identified. Then, the criteria are screened by experts' views. The expert's views are gathered through a questionnaire. Using DEMATEL method, the criteria are prioritized and their weights are extracted. At the next steps, insurance companies are evaluated and ranked through PROMETHEE method. Here, the analysis results of the previous steps are used to evaluate and rank the insurance companies. The weights determine the type of criteria (min or max) and the ranking process is performed using PROMETHEE method. All relevant data are collected from Tehran Stock Exchange as well as insurance companies' websites. The data include those contained in financial statements, and reports of the board of directors and general assemblies. By implementing the evaluation process through PROMETHEE method, the score of each criterion is obtained and finally each insurance company is ranked.

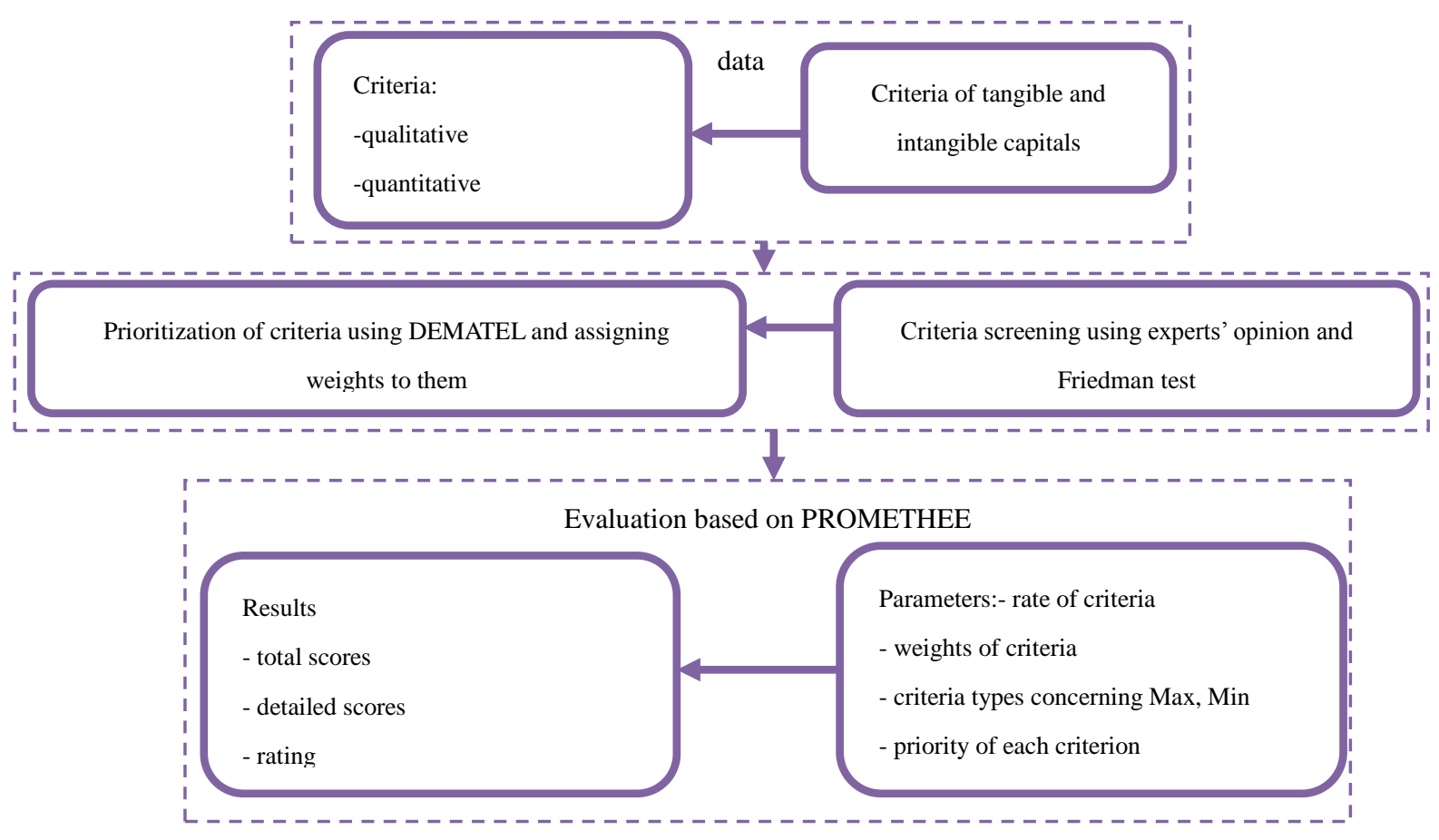

Figure 2. Methodology of the research

\subsection{Analysis Based on Investigational Findings}

After reviewing the literature (Persian \& Latin) and according to experts' comments, criteria presented in Table 2 were considered for evaluation. 
Table 2. Criteria and dimensions of the investigation

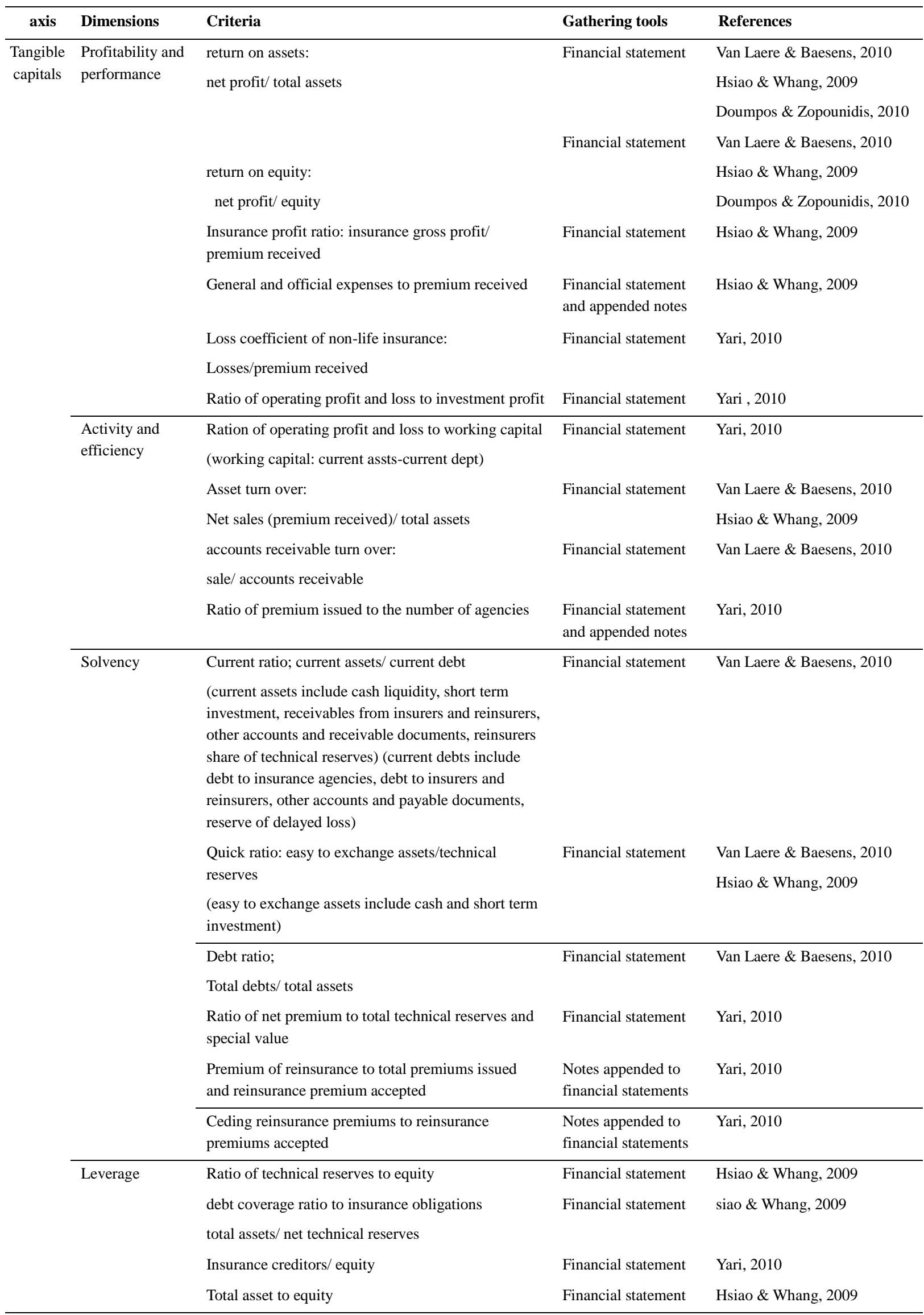




\begin{tabular}{|c|c|c|c|c|}
\hline \multirow[t]{18}{*}{$\begin{array}{l}\text { Intangible } \\
\text { capitals }\end{array}$} & \multirow[t]{8}{*}{ Human capital } & $\begin{array}{l}\text { Knowledge } \\
\text { - percentage of employees with higher education }\end{array}$ & \multirow{2}{*}{$\begin{array}{l}\text { Annual report of } \\
\text { board activity } \\
\text { Annual report of } \\
\text { board activity }\end{array}$} & $\begin{array}{l}\text { Doumpos \& Zopounidis, } 2010 \\
\text { Hunter et al., } 2005\end{array}$ \\
\hline & & $\begin{array}{l}\text { Experience } \\
\text { - number of employees }\end{array}$ & & $\begin{array}{l}\text { Doumpos \& Zopounidis, } 2010 \\
\text { Chen, } 2010\end{array}$ \\
\hline & & - average age of employees & \multirow{5}{*}{$\begin{array}{l}\text { Annual report of } \\
\text { board activity }\end{array}$} & Hunter et al., 2005 \\
\hline & & - average years of cooperation with company & & \multirow{4}{*}{ Hunter et al., 2005} \\
\hline & & $\begin{array}{l}\text { Education } \\
\text { - hours devoted to employees education }\end{array}$ & & \\
\hline & & - education hours/ number of employees & & \\
\hline & & $\begin{array}{l}\text { - number of congresses and meeting in which } \\
\text { employees and managers participated }\end{array}$ & & \\
\hline & & $\begin{array}{l}\text { Employee productivity } \\
\text { - per capita premium issued: the number of } \\
\text { insurance issued/ total number of personnel }\end{array}$ & $\begin{array}{l}\text { Annual report of } \\
\text { board activity }\end{array}$ & Shafiei \& Selahnejad, 2010 \\
\hline & \multirow[t]{5}{*}{$\begin{array}{l}\text { Structural } \\
\text { capital }\end{array}$} & $\begin{array}{l}\text { Hardware power of organization } \\
\text { - rate of investment in fixed asset and official } \\
\text { equipment }\end{array}$ & $\begin{array}{l}\text { Annual report of } \\
\text { board activity }\end{array}$ & Hunter et al., 2005 \\
\hline & & $\begin{array}{l}\text { Software power of organization } \\
\text { - software and software services }\end{array}$ & $\begin{array}{l}\text { Annual report of } \\
\text { board activity }\end{array}$ & Young Accountants, 2007 \\
\hline & & $\begin{array}{l}\text { Organization tendency to receive national and } \\
\text { international standards }\end{array}$ & $\begin{array}{l}\text { Annual report of } \\
\text { board activity }\end{array}$ & Hunter et al., 2005 \\
\hline & & - the number of ISO9000 certificates & & \\
\hline & & - the number of certificates & & \\
\hline & \multirow[t]{5}{*}{$\begin{array}{l}\text { Relational } \\
\text { capital }\end{array}$} & $\begin{array}{l}\text { Company market share } \\
\text { - percentage of company market share }\end{array}$ & $\begin{array}{l}\text { Annual report of } \\
\text { board activity }\end{array}$ & Shafia et al., 2009 \\
\hline & & $\begin{array}{l}\text { Number of distribution channels } \\
\text { - number of sale networks }\end{array}$ & $\begin{array}{l}\text { Annual report of } \\
\text { board activity }\end{array}$ & Shafia et al., 2009 \\
\hline & & $\begin{array}{l}\text { Number of desirable contracts indicating } \\
\text { performance status }\end{array}$ & Financial statement & Shafia et al., 2009 \\
\hline & & $\begin{array}{l}\text { Relation with financial institutes } \\
\text { - investment rate in monetary and financial markets }\end{array}$ & $\begin{array}{l}\text { Financial statement } \\
\text { and appended notes }\end{array}$ & Chen, 2010 \\
\hline & & $\begin{array}{l}\text { Costumers } \\
\text { - costumers' satisfaction criterion }\end{array}$ & $\begin{array}{l}\text { Annual report of } \\
\text { board activity }\end{array}$ & $\begin{array}{l}\text { Young Accountants, } 2007 \\
\text { Hunter et al., } 2005\end{array}$ \\
\hline
\end{tabular}

Considering large number of the criteria, a questionnaire was offered to executive and scientific experts to prioritize and screen the criteria. Data analysis was performed by Friedman test using SPSS software. Eighteen criteria with the lowest scores were finally omitted.

\section{Achieving an Integrated Model of Tangible and Intangible Capitals}

The criteria should be organized with a proper and accurate structure of direct and indirect relationships. Systematic organizing of existing data will make it possible to achieve a defined and integrated model (hierarchy) of obvious relations among the assumed factors. A method in this regard is DEMATEL (Asgharpour, 2003). By means of this method, the rate and the way of interactions among the components in terms of affecting on each other from cause-effect vision is determined. To achieve this, criteria remained from the previous step are put on the head of a diagraph; pairwise comparisons are performed and experts' judgment is only asked for direct relationships among the elements. The severity of final relations of the elements is presented as scoring (0-40). In this study, assigning scores to the elements is performed by five insurance experts. Final scores, in terms of the existing relations, from the diagraph are presented as a matrix $\mathrm{M}^{\wedge}$. Every input of the matrix $\mathrm{M}^{\wedge}$ is multiplied 
by inverse of the largest row sum of the matrix $\left(\alpha \times M^{\wedge}=M\right)$. Equation (1) estimates possible severity of all the direct and indirect relations (obtained by experts' answers) for the assumed diagraph (Asgharpour, 2003).

$$
\sum_{t \rightarrow \infty}=S=M+M^{2}+M^{3}+\ldots+M^{t}=\frac{M\left(1-M^{t}\right)}{(1-M)} ; \lim _{t \rightarrow \infty} M^{t}=0=\frac{M}{(1-M)}=M(1-M)^{-1}
$$

Influencing order of the assumed elements of a problem on other elements or the influence under which they exist will determines possible structure of those elements hierarchy in improving or solving the problem.

Table 3. Table of influencing order of the elements on each other

\begin{tabular}{lccccccc}
\hline $\begin{array}{c}\text { Order of } \\
\text { elements }\end{array}$ & $\begin{array}{c}\text { Based on } \\
\text { (R-J) }\end{array}$ & $\begin{array}{c}\text { Order of } \\
\text { elements }\end{array}$ & $\begin{array}{c}\text { Based on } \\
(\mathbf{R}+\mathbf{J})\end{array}$ & $\begin{array}{c}\text { Order of } \\
\text { elements }\end{array}$ & $\begin{array}{c}\text { Based on the highest } \\
\text { column sum J }\end{array}$ & $\begin{array}{c}\text { Order of } \\
\text { elements }\end{array}$ & $\begin{array}{c}\text { Based on the } \\
\text { highest row sum R }\end{array}$ \\
\hline 1.4754154 & M14 & 11.476736 & M18 & 6.0614118 & M18 & 5.5252162 & M11 \\
1.2995421 & M11 & 10.860632 & M12 & 5.4578522 & M12 & 5.4297633 & M9 \\
0.9752368 & M10 & 10.181325 & M19 & 5.3839069 & M13 & 5.4153245 & M18 \\
0.9695353 & M9 & 9.9210764 & M17 & 5.3608591 & M3 & 5.4027802 & M12 \\
0.9417306 & M4 & 9.8959743 & M13 & 5.2871472 & M6 & 5.3652177 & M14 \\
0.6091984 & M17 & 9.8899913 & M9 & 5.1984573 & M16 & 5.3069969 & M19 \\
0.4326684 & M19 & 9.8786131 & M3 & 4.89652 & M7 & 5.2651374 & M17 \\
0.2761142 & M15 & 9.7508903 & M11 & 4.8800025 & M1 & 4.6843939 & M1 \\
-0.055072 & M12 & 9.7291822 & M16 & 4.8743285 & M19 & 4.5632624 & M8 \\
-0.195609 & M1 & 9.5643964 & M1 & 4.8291179 & M8 & 4.5307249 & M16 \\
-0.265856 & M8 & 9.3923803 & M8 & 4.655939 & M17 & 4.5177544 & M3 \\
-0.479331 & M5 & 9.25502 & M14 & 4.4907432 & M2 & 4.5120674 & M13 \\
-0.51323 & M2 & 8.6890763 & M7 & 4.4680228 & M9 & 4.203758 & M10 \\
-0.646087 & M18 & 8.4682566 & M2 & 4.259068 & M5 & 3.9775134 & M2 \\
-0.667732 & M16 & 8.038805 & M5 & 4.2256741 & M11 & 3.9570553 & M6 \\
-0.843105 & M3 & 7.569099 & M15 & 3.8898023 & M14 & 3.9226066 & M15 \\
-0.87184 & M13 & 7.4322792 & M10 & 3.6464924 & M15 & 3.7928263 & M7 \\
-1.103424 & M7 & 6.1981904 & M4 & 3.2285212 & M10 & 3.779737 & M5 \\
-4.891442 & M6 & 5.6828527 & M6 & 2.6282299 & M4 & 3.5699605 & M4 \\
\hline & & & & & & & \\
\hline
\end{tabular}

So order of elements from column R shows the hierarchy of influencing elements and that of column $\mathrm{J}$ shows the influenced elements. Real location of each element in final hierarchy is determined by $(R-J)$ and $(R+J)$ so that (R-J) shows the position of an element (along width axis) and this position will be undoubtedly an influencing (penetrating) if (R-J) is positive; and will be influenced (receiver) if (R-J) is negative. $(R+J)$ indicates total severity of an element (along length axis) in terms of influencing or being influenced (Asgharpour, 2003).

\subsection{Preference severity of Elements (Assigning Weight to Elements)}

If matrix D is $a_{i j}=\frac{w_{i}}{w_{j}}$, then equation2 will give the weights. 


$$
\mathrm{D}=\left[\begin{array}{ccc}
\frac{w_{1}}{w_{2}} & \ldots & \frac{w_{1}}{w_{m}} \\
\ddots & & \\
\frac{w_{m}}{w_{1}} & \cdots & \frac{w_{m}}{w_{m}}
\end{array}\right] \quad\left\{\prod_{j=1}^{m} a_{i j}\right\}^{\frac{1}{m}}=g_{i} ;\{j=1, \ldots m\}:(\text { Geometric mean of each row })
$$

To prepare the data for entering final step (rating of insurance companies) some tools such as financial statements, their appended notes and annual report of board activity were used. In this investigation, content analysis method was used for analyzing annual report.

\subsection{Content Analysis Steps}

1) Step of preparation and organization: in content analysis, subject adopting should be in agreement with selection of the analyzed content. In the present investigation, written documents and data entitled "board activity report" was used for measuring the intangible capitals.

2) Material (message) evaluation: material evaluation means to encode them. Encoding is process by which raw data are regularly placed in units making it possible to exactly describe the content, which includes steps below:

a- Selection of units (record unit): selection of investigation unit which is a main part of content analysis, depends on investigation goal. These units include word, sentence, contents, paragraph or whole the material. Our goal in this study was to measure the criteria of intangible capitals based on which complete body of the annual report of activity was investigated.

b- Counting method: the way of evaluating the units includes appearance of some concepts and images, time devoted to do special assignment and so on. Counting unit can be adopted based on categories related to the topic as well. Counting unit in this study was based on the categories.

c- Categorization: a critical step in content analysis is to identify and select the categories and sub-categories of the investigation. Categorizations of other authors can be used as template for developing investigational categories and sub-categories. Categories and sub-categories of the present study are presented in Table 2 .

d- Determining statistical population: like for other scientific investigations, determining the statistical population is necessary for content analysis. In this study, annual report of board of insurance companies accepted in Tehran stock exchange from 2010-2012 was investigated and analyzed.

3) Data processing: the final step in content analysis is processing of encoded data. This can be done in two ways: manual or by computer (Sarmad et al., 2006). Data process in the present study was performed manually because of limited number of the criteria. Each category and concept within the documents was investigated many times and finally recorded.

\subsection{Application of Multiple Criteria Decision Methods in Rating of Insurance Companies}

Multiple criteria methods such as PROMETHEE are always used in rating issue. Preferred structured method is used for enrichment of evaluations in rating process. Rating steps using PROMETHEE are:

a) Formation of evaluation table: evaluation table is the start point of PROMETHEE which was formed by visual PROMETHEE software in this investigation.

b) Calculating preference function: rating of the options is performed using pairwise comparison of options in each criterion. The comparison is measured using a predetermined preference function with range of $[0,+1]$. For preference function $\mathrm{P}$, options $\mathrm{a}$ and $\mathrm{b}$ and criterion $\mathrm{j}$ exist:

$$
P_{j}(a, b)=P_{j}\left[d_{j}(a, b)\right]
$$

$d_{j}(a, b)=f_{j}(a)-f_{j}(b)$ Shows size difference in the $\mathrm{j}^{\text {th }}$ criterion. If $f_{j}(a)-f_{j}(b)$, then $P_{j}(a, b)$ will be zero and by increase in $f_{j}(a)-f_{j}(b)$, the value is increased and when the difference is high enough, value of $P_{j}(a, b)$ reaches to one(Omidi et al., 2011). Preference function of each criterion is often determined by nature of the criterion and decision maker's vision. There are six generalized criteria for preference function out of which the fifth method (linear) was used in this investigation. 
Table 4. Decision making matrix (D)

\begin{tabular}{|c|c|c|c|c|c|c|c|c|c|c|c|c|c|c|c|c|c|c|c|}
\hline 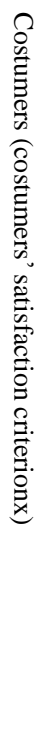 & 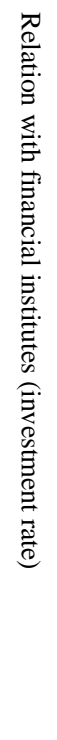 & 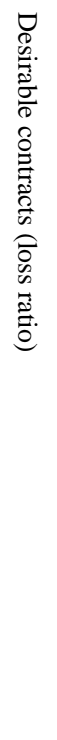 & 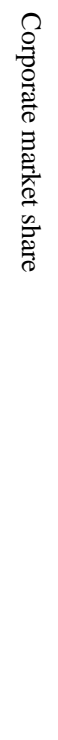 & 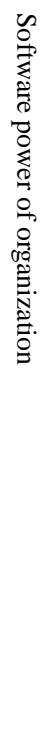 & 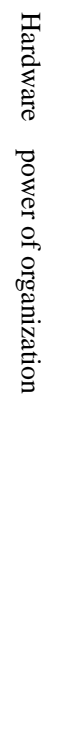 & 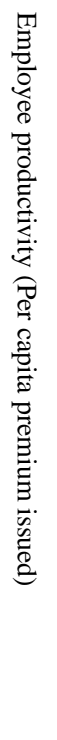 & 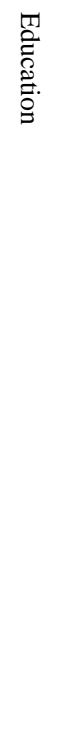 & 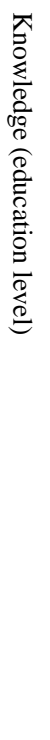 & 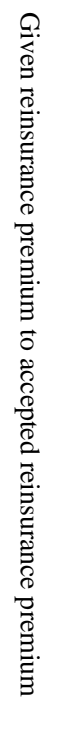 & 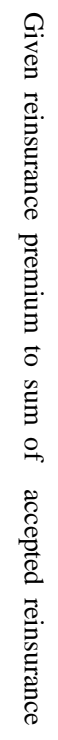 & 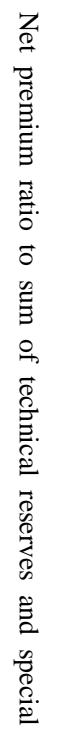 & 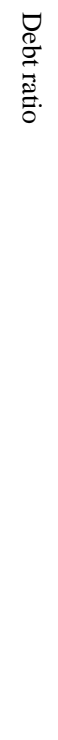 & 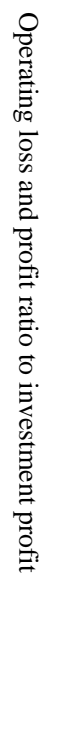 & 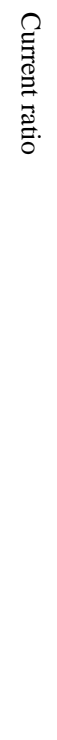 & 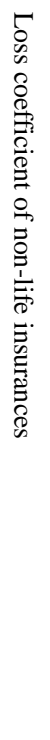 & 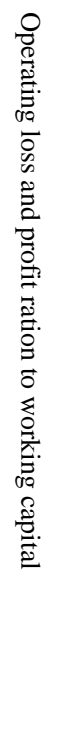 & 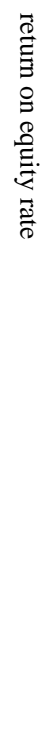 & 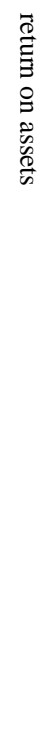 & 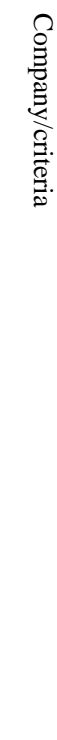 \\
\hline $\bar{N}$ & $\begin{array}{l}\stackrel{N}{N} \\
\stackrel{\infty}{0} \\
\stackrel{\infty}{\infty}\end{array}$ & in & $\begin{array}{l}\overrightarrow{0} \\
\dot{f}\end{array}$ & 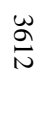 & $\begin{array}{l}\text { N } \\
\text { Oे } \\
\text { ऽ }\end{array}$ & $\begin{array}{l}\vec{E} \\
\stackrel{+}{+} \\
\dot{N}\end{array}$ & 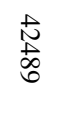 & $\stackrel{\sim}{\infty}_{\infty}$ & $\begin{array}{l}\stackrel{N}{\sim} \\
\stackrel{\sim}{\infty} \\
\mathbb{N} \\
\infty\end{array}$ & $\begin{array}{l}\text { i } \\
\text { 心 }\end{array}$ & $\underset{\mathrm{d}}{\stackrel{0}{0}}$ & $\begin{array}{l}0 \\
\infty \\
\dot{\omega}\end{array}$ & $\begin{array}{l}\circ \\
\dot{\circ} \\
\dot{0}\end{array}$ & 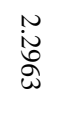 & $\underset{\vec{I}}{\stackrel{P}{*}}$ & $\stackrel{\stackrel{0}{\sigma}}{\stackrel{\sigma}{a}}$ & $\begin{array}{l}\stackrel{0}{0} \\
\stackrel{0}{\circ}\end{array}$ & $\begin{array}{l}\dot{0} \\
\dot{\infty}\end{array}$ & 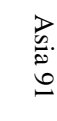 \\
\hline$u$ & 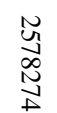 & : & $\vec{\sigma}$ & 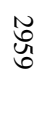 & $\begin{array}{l}\vec{v} \\
\text { Uू. } \\
\text { Na }\end{array}$ & $\begin{array}{l}\vec{t} \\
\text {. } \\
\dot{3}\end{array}$ & $\underset{\vec{N}}{\stackrel{\vec{N}}{ }}$ & $\stackrel{\leftrightarrow}{u}^{\circ}$ & 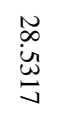 & $\begin{array}{l}\stackrel{0}{\mathbf{N}} \\
\text { Nu }\end{array}$ & $\begin{array}{r}\overrightarrow{\dot{\infty}} \\
\stackrel{.}{+}\end{array}$ & 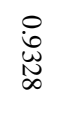 & $\dot{w}_{\substack{\infty \\
\infty}}^{0}$ & 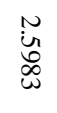 & $\stackrel{\ominus}{\geq}$ & $\stackrel{\stackrel{0}{0}}{\stackrel{0}{0}}$ & $\stackrel{\circ}{\stackrel{0}{\pi}}$ & $\stackrel{\dot{0}}{\stackrel{0}{\circ}}$ & 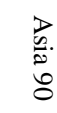 \\
\hline 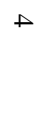 & $\begin{array}{l}\text { N } \\
\text {. } \\
心 \\
.\end{array}$ & 它 & $\underset{\sim}{\vec{\omega}}$ & 0 & 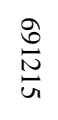 & $\begin{array}{l}\underset{N}{\mathbb{N}} \\
\dot{\omega}\end{array}$ & 0 & $\dot{\omega}_{\sigma}$ & $\begin{array}{l}\vec{\omega} \\
\dot{\mathscr{b}} \\
+\end{array}$ & $\begin{array}{l}\text { O } \\
\dot{\tilde{O}} \\
\stackrel{0}{*}\end{array}$ & : & $\begin{array}{l}\stackrel{8}{0} \\
\stackrel{N}{N}\end{array}$ & 㝘 & 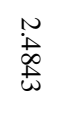 & نे & $\begin{array}{l}\text { ¿े. } \\
\text { 岕 }\end{array}$ & $\begin{array}{l}\stackrel{0}{\infty} \\
\infty \\
\infty\end{array}$ & 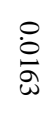 & 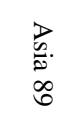 \\
\hline$\varpi$ & 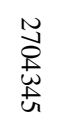 & :ू & $\begin{array}{l}u \\
\dot{\infty}\end{array}$ & $\vec{\sigma}$ & $\begin{array}{l}\text { U. } \\
\text { 苟 } \\
\text { t }\end{array}$ & 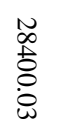 & $\begin{array}{l}\text { के } \\
\text { 去 }\end{array}$ & ĭ & $\begin{array}{l}\vec{a} \\
\dot{\infty} \\
\vec{y} \\
u\end{array}$ & $\begin{array}{l}\text { i } \\
\text { 宫 }\end{array}$ & $\underset{\vec{\omega}}{\vec{w}}$ & 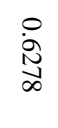 & \begin{tabular}{l}
$\dot{0}$ \\
$\dot{\omega}$ \\
\multirow{u}{u}{}
\end{tabular} & $\begin{array}{l}\stackrel{N}{u} \\
\stackrel{\infty}{\infty}\end{array}$ & iूn & 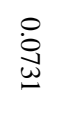 & : & 悤 & $\begin{array}{l}\stackrel{B}{\circ} \\
\stackrel{0}{\circ}\end{array}$ \\
\hline $\bar{N}$ & 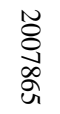 & in & $\dot{\overrightarrow{0}}$ & 岇 & $\begin{array}{l}\text { } \\
\text { ڤ̆ } \\
\text { ù }\end{array}$ & $\begin{array}{l}\tilde{U} \\
\text { o } \\
\dot{0}\end{array}$ & $\frac{t}{\stackrel{t}{0}}$ & in & $\begin{array}{l}\text { O } \\
\dot{0} \\
\stackrel{+}{0} \\
0\end{array}$ & $\begin{array}{l}\stackrel{0}{\vec{w}} \\
\text { Ju }\end{array}$ & 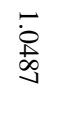 & $\begin{array}{l}0 \\
\infty \\
\stackrel{\infty}{N}\end{array}$ & 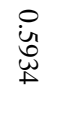 & $\begin{array}{l}\stackrel{\tilde{N}}{\tilde{N}} \\
\stackrel{\infty}{=}\end{array}$ & $\stackrel{\circ}{\dot{\infty}}$ & $\begin{array}{l}\dot{\dot{D}} \\
\dot{\infty} \\
\dot{+}\end{array}$ & $\begin{array}{l}\underset{N}{N} \\
\pm \\
\pm\end{array}$ & 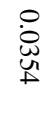 & $\begin{array}{l}\mathbb{Z} \\
\stackrel{0}{0}\end{array}$ \\
\hline$\overline{0}$ & 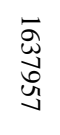 & ஷ் & $\begin{array}{l}u \\
\infty \\
+\infty\end{array}$ & 岁 & $\begin{array}{l}\text { Un } \\
\text { 怘 } \\
\infty\end{array}$ & 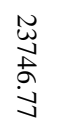 & $\begin{array}{l}\tilde{N} \\
\stackrel{E}{0}\end{array}$ & 夜 & $\begin{array}{l}\stackrel{F}{+} \\
\stackrel{0}{0} \\
\stackrel{\circ}{\circ}\end{array}$ & $\begin{array}{l}0 \\
\text { i } \\
\text { o } \\
+\end{array}$ & $\begin{array}{l}\text { : } \\
\text { Qे }\end{array}$ & 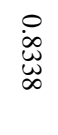 & 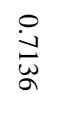 & $\begin{array}{l}n \\
\dot{8} \\
\dot{1}\end{array}$ & $\stackrel{\vec{\omega}}{\mathrm{\omega}}$ & 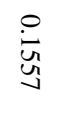 & $\begin{array}{l}\text { 芯 } \\
\text { N }\end{array}$ & $\begin{array}{l}\stackrel{0}{\circ} \\
\stackrel{0}{0}\end{array}$ & 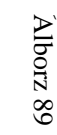 \\
\hline$\sigma$ & 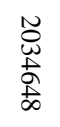 & $\underset{\infty}{\infty}$ & $\dot{\vec{g}}$ & $\underset{\circlearrowleft}{\vec{U}}$ & $\begin{array}{l}\vec{D} \\
\text { Dे } \\
\text { J }\end{array}$ & $\begin{array}{l}\underset{\sim}{\tilde{N}} \\
\stackrel{N}{2} \\
\&\end{array}$ & 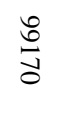 & : & $\begin{array}{l}\vec{a} \\
\stackrel{+}{ \pm} \\
w\end{array}$ & $\begin{array}{l}\text { i } \\
\text { o. } \\
\text { un }\end{array}$ & $\begin{array}{l}\overrightarrow{\tilde{u}} \\
\text { on }\end{array}$ & \begin{tabular}{l} 
o \\
$\dot{0}$ \\
\multirow{\infty}{\infty}{}
\end{tabular} & 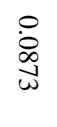 & $\begin{array}{l}\stackrel{n}{0} \\
\stackrel{0}{0}\end{array}$ & ì & $\begin{array}{l}0 \\
\text { : } \\
\text { un }\end{array}$ & $\begin{array}{l}\dot{U} \\
\text { 亲 }\end{array}$ & $\begin{array}{l}\stackrel{0}{0} \\
\dot{0} \\
\stackrel{0}{0}\end{array}$ & 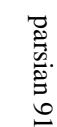 \\
\hline N & 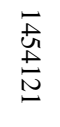 & $\underset{\infty}{\stackrel{\infty}{\infty}}$ & $\begin{array}{l}u \\
\dot{o}\end{array}$ & 颉 & 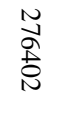 & 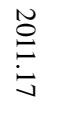 & $\begin{array}{l}\stackrel{\omega}{\mathbb{A}} \\
\stackrel{+}{A}\end{array}$ & ì & $\begin{array}{l}\infty \\
\infty \\
\dot{\infty} \\
\stackrel{\infty}{N}\end{array}$ & $\begin{array}{l}\stackrel{0}{\tilde{W}} \\
\stackrel{్}{+}\end{array}$ & 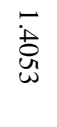 & 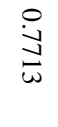 & $\begin{array}{l}\stackrel{N}{N} \\
\stackrel{N}{\infty}\end{array}$ & $\begin{array}{l}n \\
\stackrel{0}{0} \\
\stackrel{D}{+}\end{array}$ & in & 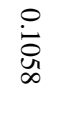 & $\frac{i}{u}$ & $\begin{array}{l}\text { Oे } \\
\text { 总 }\end{array}$ & 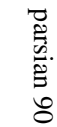 \\
\hline $\bar{\omega}$ & $\begin{array}{l}\overrightarrow{\widehat{D}} \\
\stackrel{0}{N} \\
\vec{N}\end{array}$ & $\dot{8}$ & $\ddot{a}$ & $\overrightarrow{\mathrm{N}}$ & 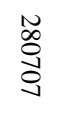 & $\begin{array}{l}\infty \\
\infty \\
\infty \\
\dot{\sigma}\end{array}$ & 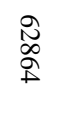 & $\stackrel{\circ}{0}$ & 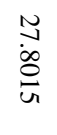 & $\begin{array}{l}\stackrel{i}{\sim} \\
\text { W. }\end{array}$ & $\underset{\dot{\omega}}{\vec{\omega}}$ & $\begin{array}{l}\stackrel{.}{\mathbf{W}} \\
\text { }\end{array}$ & $\begin{array}{l}\vec{\infty} \\
\dot{\infty} \\
\stackrel{ \pm}{ \pm}\end{array}$ & $\begin{array}{l}\overrightarrow{\tilde{o ̆}} \\
\dot{\sigma}\end{array}$ & ì & 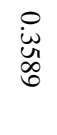 & 总 & 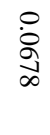 & 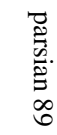 \\
\hline 。 & $\begin{array}{l}\bar{N} \\
\stackrel{N}{u} \\
u\end{array}$ & $\underset{\ddot{n}}{\dot{n}}$ & $\begin{array}{l}\ddot{o}_{0} \\
\dot{8}\end{array}$ & $\underset{⿱ 士 心}{\vec{E}}$ & 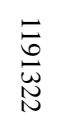 & $\begin{array}{l}\overrightarrow{0} \\
\text {. } \\
\dot{\text { II }} \\
\infty\end{array}$ & $\begin{array}{l}\text { 营 } \\
\text {. }\end{array}$ & $\stackrel{\ominus}{\vec{y}}$ & $\begin{array}{l}\infty \\
\dot{\infty} \\
\dot{\infty} \\
\mathbb{\infty}\end{array}$ & 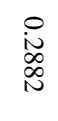 & $\frac{\dot{q}}{4}$ & $\begin{array}{l}0 \\
\text { o } \\
\text { o } \\
\text { in }\end{array}$ & 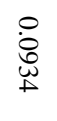 & $\begin{array}{l}\tilde{N} \\
\tilde{a} \\
\omega\end{array}$ & $\stackrel{\vec{I}}{ }$ & $\begin{array}{l}\text { : } \\
\text { 定 }\end{array}$ & 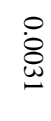 & 安 & 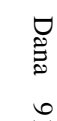 \\
\hline
\end{tabular}




\begin{tabular}{|c|c|c|c|c|c|c|c|c|c|c|c|c|c|c|c|c|c|c|c|}
\hline $\bar{\sigma}$ & 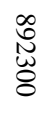 & $\stackrel{\circ}{\ddot{d}}$ & $\ddot{\omega}$ & $\underset{w}{\infty}$ & $\begin{array}{l}\text { N } \\
\mathbb{N} \\
\mathbb{N} \\
\text { Un }\end{array}$ & 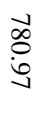 & $\begin{array}{l}\text { ?. } \\
\text { U్ర }\end{array}$ & $\stackrel{\ominus}{\vec{I}}$ & $\begin{array}{l}+ \\
\infty \\
\infty \\
\infty \\
\infty\end{array}$ & $\begin{array}{l}\stackrel{\circ}{\sim} \\
\underset{\omega}{\infty}\end{array}$ & $\underset{\stackrel{\infty}{\infty}}{\vec{\infty}}$ & $\begin{array}{l}0 \\
\dot{0} \\
\stackrel{1}{+}\end{array}$ & 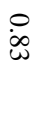 & $\underset{\sim}{\stackrel{+}{0}}$ & $\stackrel{\circ}{\infty}$ & $\begin{array}{l}\stackrel{0}{0} \\
\dot{1}\end{array}$ & 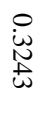 & $\begin{array}{l}\stackrel{0}{8} \\
\dot{\infty} \\
\stackrel{\infty}{+}\end{array}$ & 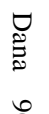 \\
\hline$\Xi$ & 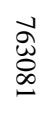 & $\stackrel{0}{u}$ & $\underset{b}{\infty}$ & U్ర & $\begin{array}{l}\stackrel{N}{W} \\
\stackrel{N}{U} \\
\text { U. }\end{array}$ & $\begin{array}{l}\stackrel{\infty}{\infty} \\
\stackrel{+}{+}\end{array}$ & 记 & 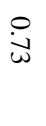 & $\begin{array}{l}\underset{\infty}{\omega} \\
\stackrel{+}{\omega} \\
+\end{array}$ & $\begin{array}{l}\text { 엉 } \\
\text { ్ㅠㅇ }\end{array}$ & $\begin{array}{l}\text { 岕 } \\
\text { స్ర }\end{array}$ & $\begin{array}{l}\text { 유 } \\
\$ \\
\$\end{array}$ & $\underset{\mathscr{\infty}}{\stackrel{0}{0}}$ & $\begin{array}{l}\text { N } \\
\text { N̊ } \\
\text { g }\end{array}$ & 家 & 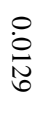 & $\stackrel{0}{\mathfrak{\sigma}}$ & $\begin{array}{l}\circ \\
\dot{8} \\
\stackrel{8}{\circ}\end{array}$ & $\begin{array}{l}\underset{\mathscr{N}}{\tilde{N}} \\
\underset{0}{\infty}\end{array}$ \\
\hline$\underset{\not}{3}$ & 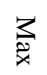 & 沓 & $\underset{\ddot{x}}{3}$ & $\underset{\substack{x \\
x}}{3}$ & $\underset{\tilde{x}}{3}$ & 㒸 & $\underset{\substack{x \\
x}}{3}$ & 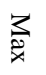 & 3 & 沓 & $\underset{\tilde{x}}{\vec{x}}$ & 党 & 录 & $\underset{\tilde{x}}{\vec{x}}$ & 3 & $\underset{\tilde{x}}{3}$ & $\underset{\tilde{x}}{3}$ & 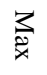 & 䓌 \\
\hline 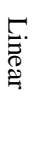 & 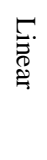 & 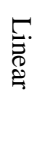 & $\begin{array}{l}\text { ․․ } \\
\stackrel{\overbrace{}}{ت}\end{array}$ & $\begin{array}{l}\stackrel{5}{\Xi} \\
\stackrel{\overbrace{}}{\rightleftarrows}\end{array}$ & 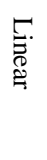 & 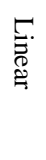 & 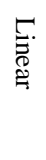 & 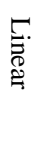 & 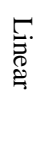 & 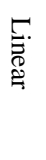 & 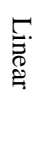 & 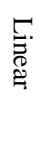 & 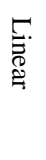 & 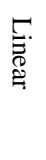 & $\begin{array}{l}\stackrel{5}{\leftrightarrows} \\
\stackrel{\overbrace{}}{\rightleftarrows}\end{array}$ & $\begin{array}{l}\stackrel{ }{\Xi} \\
\stackrel{\overbrace{}}{\rightleftarrows}\end{array}$ & 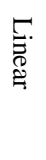 & 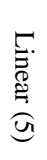 & 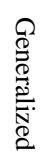 \\
\hline 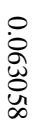 & $\begin{array}{l}0 \\
\circ \\
\circ \\
\dot{+} \\
\dot{+} \\
\text { un }\end{array}$ & $\begin{array}{l}\stackrel{0}{0} \\
\text { 冬 } \\
\text { Ŭ }\end{array}$ & 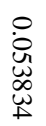 & $\begin{array}{l}\stackrel{0}{0} \\
\dot{+} \\
\stackrel{\circ}{\circ}\end{array}$ & $\begin{array}{l}\stackrel{0}{\circ} \\
\dot{d} \\
\text { ù }\end{array}$ & $\begin{array}{l}\stackrel{0}{0} \\
\stackrel{\leftrightarrow}{心} \\
\stackrel{\leftrightarrow}{\sim}\end{array}$ & $\begin{array}{l}\stackrel{ }{\circ} \\
\stackrel{2}{\star} \\
\stackrel{2}{\circ}\end{array}$ & 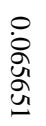 & $\begin{array}{l}0 \\
\dot{8} \\
\stackrel{+}{0} \\
\stackrel{0}{0}\end{array}$ & 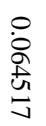 & $\begin{array}{l}0 \\
\dot{O} \\
\text { 䓌 } \\
\text { N }\end{array}$ & 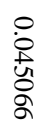 & 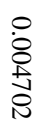 & $\begin{array}{l}\stackrel{0}{0} \\
\stackrel{+}{+} \\
\stackrel{0}{O} \\
=\end{array}$ & $\begin{array}{l}\stackrel{0}{\circ} \\
\stackrel{+}{ \pm} \\
\stackrel{ \pm}{\infty}\end{array}$ & 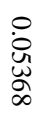 & 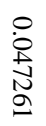 & $\begin{array}{l}\circ \\
\dot{\circ} \\
\text { Ŭ } \\
\text { ă }\end{array}$ & 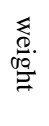 \\
\hline
\end{tabular}

c) Calculating total preference function: final rating or priority of two options is obtained by summing of priorities of all the criteria. Indeed, total priority $\pi(a, b)$ is calculated for each option a on option $b$. the higher this value, the more preferred option a; which is calculated as follows:

$$
\pi(a, b)=\sum_{j=1}^{k} w_{j} p_{j}(a, b),\left(\sum_{j=1}^{k} w_{j}=1\right)
$$

So that $\mathrm{Wj}$ is equal to weight of $\mathrm{jth}$ criterion, and the weights are determined and then normalized $\left(\sum W_{j}=1\right)$ by decision maker.

d) if number of options is more than two (denoted by n), final rating is obtained by total value of pairwise comparisons. For each option and by considering other options, rating stream can be calculated:

"positive rating stream or output stream"

$$
\emptyset^{+}(a)=\frac{1}{n-1} \sum_{x \in A} \pi(a, x)
$$

This stream shows how much priority option "a" has over other options. This stream is indeed power of option a. the highest $\emptyset^{+}(a)$ means the best option.

"positive rating stream or output stream"

$$
\varnothing^{-}(a)=\frac{1}{n-1} \sum_{x \in A} \pi(a, x)
$$

This stream shows how much priority other options have over option a. this stream is indeed weakness of option a. the lowest $\varnothing^{-}(a)$ shows the best option.

Rating of options can be done by positive or negative stream. These two rating are not usually identical. Therefore, a partial rating can be accomplished by separate evaluations of two streams $\emptyset^{+}$and $\emptyset^{-}$. (PROMETHEE I rating).

Decision maker always wants complete rating because decision making is simpler in this manner. This can be achieved by estimating net rating stream.

$$
\varnothing(a)=\emptyset^{+}(a)-\emptyset^{-}(a)
$$

This stream is the result of balance between positive and negative streams. Higher net stream indicates the superior option. This version of the method is called PROMETHEE II : 


$$
\begin{array}{ccc}
\left(a P^{11} b\right) & \text { if } & \varnothing(\mathrm{a})>\varnothing(\mathrm{b}) \\
\left(a I^{11} b\right) & \text { if } & \text { ?a) }>\varnothing(\mathrm{b})
\end{array}
$$

In this manner, all the options can be compared and no option will be incomparable (Asgharzade \& Nasrollahi, 2007).

Results of complete rating and according to Figure 3 are: Alborz 91, Asia 91, Parsian 91, Alborz 90, Asia 90, Parsian 89, Parsian 90, Alborz 89, Dana 91, Asia 89, Dana 90, and Dana 89.

\begin{tabular}{|l|r|r|r|}
\hline \multicolumn{1}{|l|}{\begin{tabular}{l} 
Ф Preference Flows \\
\hline
\end{tabular}} & Phi+ & Phi- & Phi \\
\hline bime asia 91 & 0,2614 & 0,0872 & 0,1742 \\
\hline bime asia 90 & 0,2207 & 0,1431 & 0,0776 \\
\hline bime asia 89 & 0,0986 & 0,2630 & $-0,1645$ \\
\hline bime alborz 91 & 0,3076 & 0,0559 & 0,2517 \\
\hline bime alborz 90 & 0,2246 & 0,1235 & 0,1011 \\
\hline bime alborz 89 & 0,1553 & 0,2246 & $-0,0693$ \\
\hline bime parsian 91 & 0,2554 & 0,1012 & 0,1541 \\
\hline bime parsian 90 & 0,1884 & 0,1874 & 0,0010 \\
\hline bime parsian 89 & 0,1907 & 0,1797 & 0,0110 \\
\hline bime dana 91 & 0,1425 & 0,2586 & $-0,1161$ \\
\hline bime dana 90 & 0,0784 & 0,2723 & $-0,1940$ \\
\hline bime dana 89 & 0,0586 & 0,2855 & $-0,2269$ \\
\hline & & & \\
\hline
\end{tabular}

Figure 3. Table of prioritization stream using visual PROMETHEE software

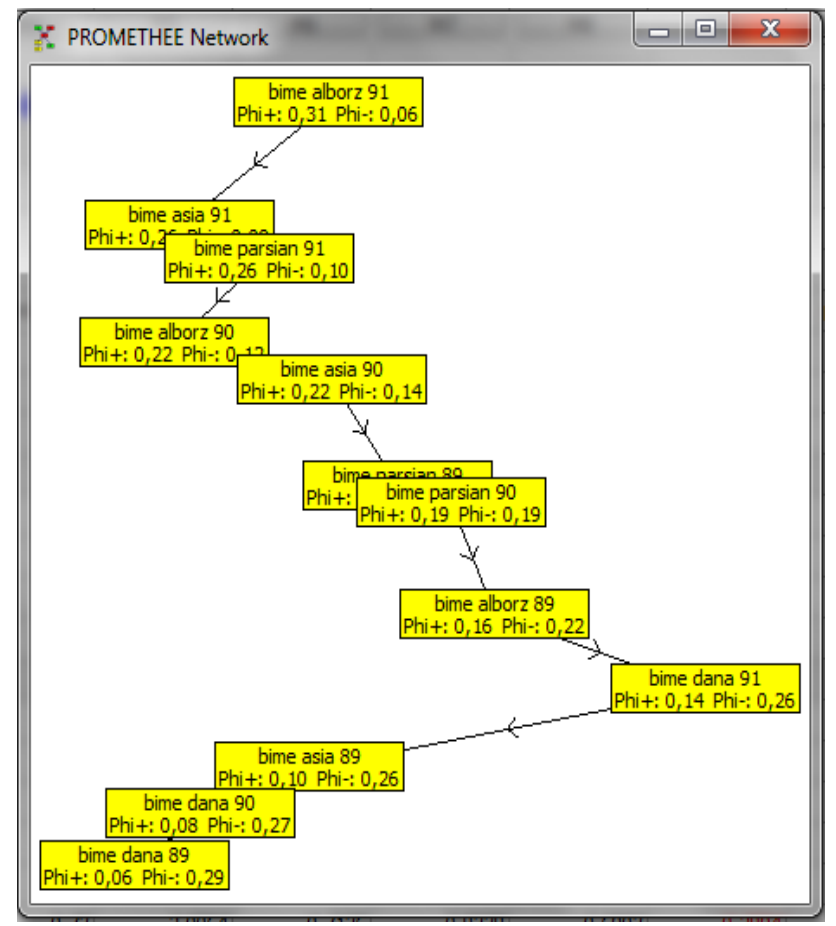

Figure 4. Networking of rating stream using visual PROMETHEE software 


\section{Conclusion and Suggestions}

This study was conducted to achieve some major purposes. The first goal was to achieve important and influencing criteria of tangible and intangible capitals in rating of Iranian insurance companies which was obtained by studying the documents and interviewing with experts (professors, experts and managers of insurance companies). The second purpose was to achieve an integrated model of tangible and intangible capitals for identifying the relations among investigated components concerning influencing rate and amount of influence receiving from cause and effect approach; this purpose was achieved using DEMATEL technique. The third purpose was rating of insurance companies using multiple criteria decision making methods for which, PROMETHEE II was used as a powerful technique proposed for multiple criteria decision making and has many advantages over other common methods. According to results obtained based on relative importance and weight of the criteria, it can be concluded that most of the studied companies are at the same level concerning their attention to criteria of tangible (financial) capitals and the most obvious difference of the companies are due to criteria of intangible capitals which are not identical in different companies, so it is better for organizations to pay more attention to this issue.

\section{Suggestions for Future Studies}

- It is recommended to use other decision making methods such as ELECTERE for rating;

- Conducting the method again using all the gathered criteria (before screening) or with criteria not applied in the present study due to limitations. This can be done using computer programming methods;

- Application of this technique for rating of other intermediate corporations such as banks and investment institutes.

\section{References}

Alavi, A., \& Ghareshi, R. (2007). Intellectual capital measurement pattern in Iranian organizations. Management Thought, 192, 127-150.

Amin, M. E., \& Kamalkhani, S. (2009). Revolution in insurance industry. Tehran: Alborz insurance publication.

Amiri, M., Mazloumi, N., \& Hejazi, M. (2011). Application of balanced scorecards and VIKOR in rating of insurance companies. Seasonal of Insurance Investigation, 26(2), 115-144.

Asgharizade, E., \& Nasrollahi, M. (2006). Rating of companies based on excellence model criteriaPROMETHEE method. Seasonal of Human Science, 11(3), 59-84.

Asgharpour, M. J. (2003). Collective Decision Making and Theory of Games via Operational Investigation Approach (1st ed.). Tehran: Publication of Tehran University.

Beker, B., Hugeslead, M., \& Olrich, D. (2009). Methods for balanced evaluation of human resource; the relation among individuals, strategy and performance. Tehran: cultural investigations publication.

Bernè, F., Ciprian, M., Fanni, M., Marassi, D., Pediroda, V., \& Aziendale, T. (2006). Multi criteria credit rating (MCCR): a credit rating assignment stream for Italian enterprises according to Basel II. MCDM 2006.

Chen, I. S., \& Chen, J. K. (2010). How to manage knowledge well? Evidence from the life insurance industry. Afr. J. Bus. Manage, 4, 3605-3617. http://www.academicjournals.org/AJBM

Dielis, M. (2007). Intellectual capital disclosure in corporate annual reports: establishing culture as a driver and discovering trends. Doctoral Dissertation, Unpublished Master's Thesis, Maastricht University.

Doumpos, M., \& Zopounidis, C. (2010). A multicriteria decision support system for bank rating. Decision Support Systems, 50(1), 55-63. http://dx.doi.org/10.1016/j.dss.2010.07.002

Financial Statements and Board Report to Ordinary Annual Metting, Taken from Kedal Net, Comprehensive Information System, Tehran Stock Exchange. Retrieved from http://www.codal.ir

Hasanzade, H., \& Zareh, M. S. (2008). Identifying criteria for evaluation of private insurance companies using balanced scorecard with experts' opinion. Seasonal of Insurance Industry, 23(3-4), 7-36.

Hasanzadeh, A., Asgari, M. M., \& Kazem, N. M. (2010). Investigating insurance position in economy and capital market of Iran. Seasonal of Insurance Industry, 25(2), 165-199.

Ho, C. A., \& Williams, S. M. (2003). International comparative analysis of the association between board structure and the efficiency of value added by a firm from its physical capital and intellectual capital resources. The International Journal of Accounting, 38(4), 465-491. http://dx.doi.org/10.1016/j.intacc.2003.09.001 
Hsiao, S. H., \& Whang, T. J. (2009). A study of financial insolvency prediction model for life insurers. Expert Systems with Applications, 36(3), 6100-6107. http://dx.doi.org/10.1016/j.eswa.2008.07.024

Hunter, L., Webster, E., \& Wyatt, A. (2005). Measuring intangible capital: a review of current practice. Australian Accounting Review, 15(36), 4-21. http://dx.doi.org/10.1111/j.1835-2561.2005.tb00288.x

Khavandkar, J., Khavandkar, E., \& Mottaghi, A. (2008). Intellectual capital, development of measuring models, publication of industrial education and investigation center.

Mckey, M. (2009). Assessing financial power of insurers. Seasonal of Insurance Industry, 37-46.

Marr, B. (2008). Impacting Future Value: How to Manage your Intellectual Capital, Management Strategy Measurement. The Society of Management Accountants of Canada, The American Institute of Certified Public Accountants, The Chartered Institute of Management Accountants.

Mehrani, S., Ganji, H., Tahriri, A., \& Asgari, M. (2009). Evaluating and rating of companies based on accounting and non-accounting information and comparing them to rating of companies in Teharn stock exchange. Journal of Capital and Development, 2(3), 7-32.

Mirzayi, H., \& Safari, A. (2009). An introduction to rating of Iranian insurance companies. News of Insurance Industry, 136/137, 16-29.

Safavi, B., \& Falahati, M. (2007). Comparative evaluation of financial performance of irani9an and foreign insurance companies their rating. Business Investigations, 24, 12-19.

Sarmad, Z., Bazargan, A., \& Hejazi, E. (2006). Investigational methods in behavioral sciences (13th ed.). Tehran: Agah Publication.

Shafia, M. A., Sohrabi, B., Raeisi, V. I., \& Faghih, M. S. (2009). A model for analytical assessment of intellectual capitals. International conference of intellectual capital management, science and technology park of Zanjan.

Shafiei, H., Abadi, H., \& Selahnrjad, A. (2008). Modern model for rating of Iranian insurance companies based intellectual capital and evaluation model based on general data. Number 16-134, Chatr Press, Parsian Insurance Company.

Van Gestel, T., Martens, D., Baesens, B., Feremans, D., Huysmans, J., \& Vanthienen, J. (2007). Forecasting and analyzing insurance companies' ratings. International Journal of Forecasting, 23(3), 513-529. http://dx.doi.org/10.1016/j.ijforecast.2007.05.001

Van Laere, E., \& Baesens, B. (2010). The development of a simple and intuitive rating system under Solvency II. Insurance: Mathematics and Economics, 46(3), 500-510. http://dx.doi.org/10.1016/j.insmatheco.2010.01.008

Yari, J. (2010). Evaluating and rating of insurance companies in Iran, perspectives and challenges. News of Insurance Industry, 144-145, 33-50.

Zekawat, M. (2003). Overview on financial rating institutes. Economical News, 100, 44-49.

\section{Copyrights}

Copyright for this article is retained by the author(s), with first publication rights granted to the journal.

This is an open-access article distributed under the terms and conditions of the Creative Commons Attribution license (http://creativecommons.org/licenses/by/3.0/). 